\title{
Loperamide Inhibits the Enhanced Intestinal Glucose Absorption of Cystic Fibrosis In Vitro
}

\author{
J. HARDCASTLE, P. T. HARDCASTLE, AND C. J. TAYLOR
}

Department of Biomedical Science, The University, Sheffield S10 2TN [J.H., P.T.H.], and Department of Paediatrics, Children's Hospital, Sheffield S10 2TH /C.J.T.J, United Kingdom

\begin{abstract}
Enhanced $\mathrm{Na}^{+}$-linked nutrient absorption has been demonstrated in the cystic fibrosis bowel and may contribute to the dehydration of the luminal contents. The ability of loperamide to inhibit glucose transport was therefore assessed in jejunal biopsy specimens from children with cystic fibrosis by measuring the increased shortcircuit current associated with active glucose absorption using a mini-Ussing chamber technique. The presence of loperamide in the luminal solution reduced the rise in shortcircuit current induced by glucose over the range of concentrations tested $\left(2.5\right.$ to $\left.40 \mathrm{mmol} \cdot \mathrm{L}^{-1}\right)$. This finding suggests that the enhanced $\mathrm{Na}^{+}$absorption, which is a feature of cystic fibrosis, is amenable to treatment and can be restored to normal levels. This result may have therapeutic implications for gastrointestinal function and may be applicable to other tissues where similar therapeutic approaches to reduce $\mathrm{Na}^{+}$and thus water absorption are being pursued. (Pediatr Res 35: 354-356, 1994)
\end{abstract}

\section{Abbreviations}

$\mathrm{CF}$, cystic fibrosis

SCC, short-circuit current

$\mathrm{CF}$ is a multiorgan disease that is characterized by abnormal ion transport across epithelia (1). It is now well established that, in $\mathrm{CF}$, epithelia that normally secrete $\mathrm{Cl}^{-}$, e.g. those lining the intestine and the airways, fail to do so, (1-7) and it has been suggested that this abnormality is responsible for the excessive dehydration of the luminal contents. The recent discovery of the CF gene (8) and evidence that its product, CF transmembrane conductance regulator, can act as a $\mathrm{Cl}^{-}$channel (9) has led to emphasis being placed on this aspect of epithelial ion transport dysfunction in CF. However, failure of $\mathrm{Cl}^{-}$secretion is not the only abnormality present in $\mathrm{CF}$ epithelia. Increased $\mathrm{Na}^{+}$absorption has also been reported in both the airway (10) and the intestine, (4-6) and this increased absorption is accompanied in the small intestine by enhanced $\mathrm{Na}^{+}$-linked nutrient absorption (11). This increased absorption will also contribute to luminal dehydration and indeed may prove to be of greater clinical significance than impaired $\mathrm{Cl}^{-}$secretion, particularly in the airway that is capable of a normal response to $\mathrm{Ca}^{2+}$-mediated secretagogues, only failing to secrete $\mathrm{Cl}^{-}$when challenged by cyclic AMP-mediated agonists (12). Thus, therapy directed at reducing the enhanced absorption in CF may prove, in the shortterm at least, more effective than attempts to activate secretion.

The antidiarrheal agent loperamide inhibits $\mathrm{Na}^{+}$-linked nutrient absorption in rat small intestine, (13) and the aim of the

Received March 2, 1993; accepted September 27, 1993.

Correspondence and reprint requests: Dr. C. J. Taylor, Department of Paediatrics, Children's Hospital, Western Bank, Sheffield S10 2TH, UK. present study was to determine whether this agent could reduce the enhanced absorption in the CF bowel.

\section{MATERIALS AND METHODS}

Patients. Peroral jejunal biopsy specimens were obtained from 11 children with $\mathrm{CF}$ who were undergoing investigation for chronic diarrhea that was unresponsive to changes in pancreatic enzyme supplementation and that was not associated with evidence of enteropathy. The diagnosis of CF was confirmed by at least two successive abnormal sweat tests, and a genetic analysis was performed to identify the defect in the $\mathrm{CF}$ gene product. Five of the control group of six patients and three of the test group of five patients were $\Delta \mathrm{F}_{508}$ homozygotes. The other three children were $\Delta \mathrm{F}_{508}$ heterozygotes, two with undefined mutations (one control, one test), both of whom had meconium ileus at diagnosis, and one with the R553X mutation (test group). All children were pancreatic insufficient. The mean age of the control group was $8.3 \mathrm{y}$ (range, 0.4 to $18.5 \mathrm{y}$ ), and the mean age of the test group was 4.3 y (range, 1.0 to 9.0 y). Intestinal morphology was normal in all cases.

Experimental procedure. The electrical activity of biopsy specimens was measured as described previously (3). Each tissue was mounted as a sheet (exposed area, $3 \mathrm{~mm}^{2}$ ) in a mini-Ussing chamber and incubated at $37^{\circ} \mathrm{C}$ with Krebs bicarbonate saline gassed with $95 \% \mathrm{O}_{2} / 5 \% \mathrm{CO}_{2}$. The serosal solution contained 10 $\mathrm{mmol} \cdot \mathrm{L}^{-1}$ glucose and the mucosal solution equimolar mannitol. The potential difference was measured with salt bridge electrodes connected by way of calomel half cells to a differential input electrometer whose output was displayed on a chart recorder (Linseis L6512, Selb, Germany). Current was applied across the tissue by conductive plastic electrodes. Tissue resistance was determined from the change in potential difference induced by a $10-\mu \mathrm{A}$ current pulse, corrected for the fluid resistance. The SCC was then calculated from potential difference and resistance measurements with Ohm's law. After 10 min of stabilization, potential difference and resistance were measured at 1 -min intervals. Each tissue was initially challenged with acetylcholine $\left(10^{-3} \mathrm{~mol} \cdot \mathrm{L}^{-1}\right.$ in serosal solution $)$, which was added after 5 -min basal readings. The serosal solution was replaced, and the tissue was allowed to restabilize. In the control tissues, glucose was added sequentially to the mucosal solutions to give concentrations of 2.5 to $40 \mathrm{mmol} \cdot \mathrm{L}^{-1}$, and the rise in SCC was taken as the difference between the maximum value achieved at each concentration and the value immediately before the start of the glucose application. The mucosal solution was then replaced, and the procedure was repeated with equimolar concentrations of mannitol to assess the effect of the increased osmolarity resulting from the mucosal addition of glucose. In the test tissues, the effects of $10 \mathrm{mmol} \cdot \mathrm{L}^{-1}$ concentrations of glucose and mannitol were tested before loperamide was added. After washing out, loperamide $\left(1.9 \times 10^{-4} \mathrm{~mol} \cdot \mathrm{L}^{-1}\right)$ was added to the mucosal solution, followed $5 \mathrm{~min}$ later by serial additions of glucose as in the control experiments. The mucosal solution was then re- 
placed, and the procedure was repeated with mannitol in the presence of loperamide. The experimental protocol is illustrated in Figure 1, which shows data from a control tissue and a test tissue.

To assess the rise in SCC associated with active glucose absorption, the change in SCC induced by each concentration of mannitol was subtracted from the increase in SCC caused by the same concentration of glucose.

Expression of results. Results are expressed as mean values \pm 1 SEM of the mean of the number of observations indicated, and the significance of loperamide action was assessed by an unpaired $t$ test.

Chemicals. Mannitol was obtained from May \& Baker Ltd. (Dagenham, UK); glucose was obtained from BDH Chemicals Ltd. (Poole, UK); and acetylcholine was obtained from Sigma Chemical Company Ltd. (Poole, UK).

\section{RESULTS}

The increase in SCC associated with active glucose absorption in jejunal biopsy specimens from children with $C F$ was greater than that observed in non-CF tissues. When data from all the biopsy specimens we studied were analyzed, the rise in SCC induced by $10 \mathrm{mmol} \cdot \mathrm{L}^{-1}$ glucose was $44.1 \pm 4.6(n=30) \mu \mathrm{A}$. $\mathrm{cm}^{-2}$ in CF tissues compared with $24.3 \pm 3.1(n=48) \mu \mathrm{A} \cdot \mathrm{cm}^{-2}$
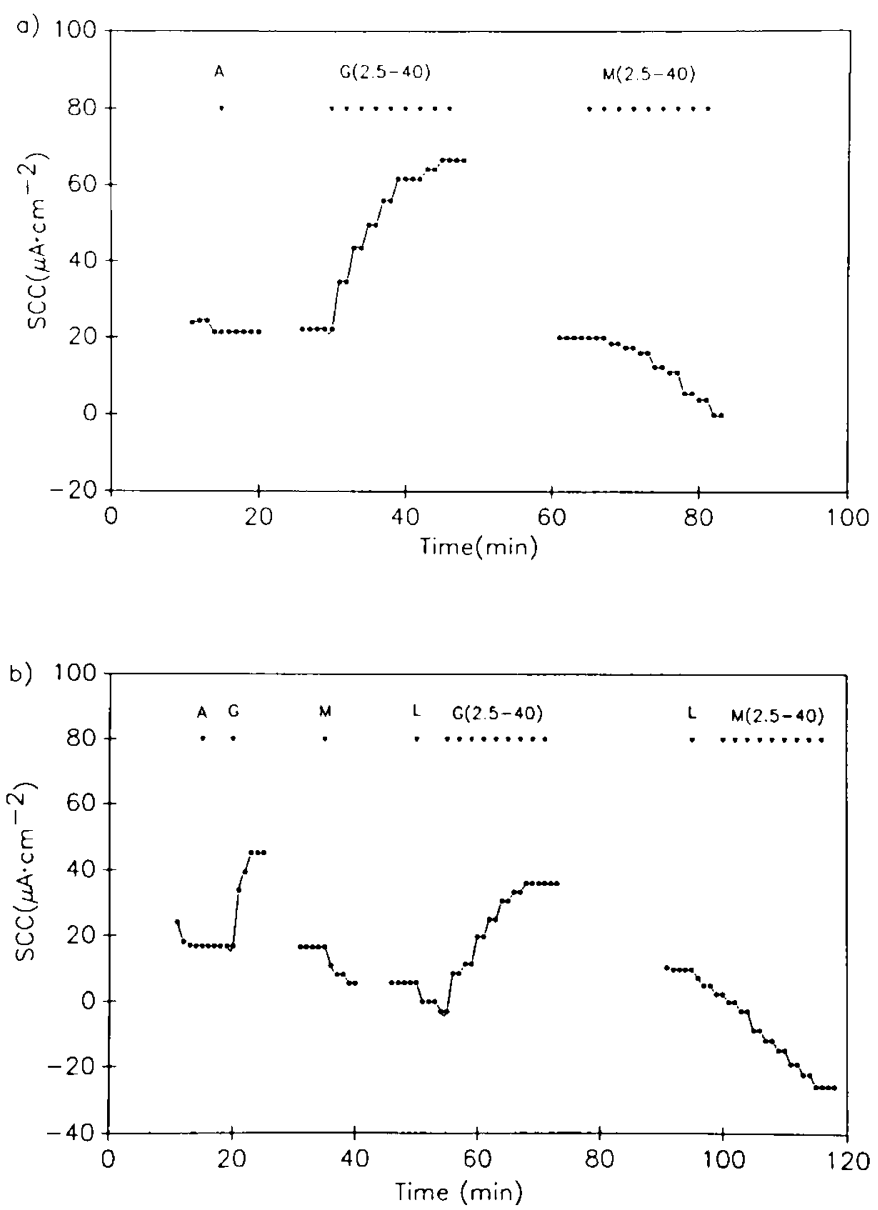

Fig. 1. SCC generated by a control $(a)$ and a test $(b)$ jejunal biopsy specimen from children with $\mathrm{CF}$. The following additions were made at the points indicated by the arrows: $A, 10^{-3} \mathrm{~mol} \cdot \mathrm{L}^{-1}$ acetylcholine; $G, 10$ $\mathrm{mmol} \cdot \mathrm{L}^{-1}$ glucose; $M, 10 \mathrm{mmol} \cdot \mathrm{L}^{-1}$ mannitol; $L, 1.9 \times 10^{-4} \mathrm{~mol} \cdot \mathrm{L}^{-1}$ loperamide; $G(2.5-40)$, serial additions of glucose to give luminal concentrations of $2.5,5,10,15,20,25,30,35$, and $40 \mathrm{mmol} \cdot \mathrm{L}^{-1} ; M / 2.5-$ 40 ), serial additions of mannitol to give luminal concentrations of 2.5 , $5,10,15,20,25,30,35$, and $40 \mathrm{mmol} \cdot \mathrm{L}^{-1}$. in non-CF tissues $(p<0.001)$, confirming, with an increased number of patients, previous observations (11).

In the CF tissues used in the present study, the basal SCC was similar in the control $(n=6)$ and test $(n=5)$ groups (control, $11.8 \pm 9.2 \mu \mathrm{A} \cdot \mathrm{cm}^{-2}$; test, $\left.5.8 \pm 3.3 \mu \mathrm{A} \cdot \mathrm{cm}^{-2}, p>0.05\right)$ and no rise in SCC occurred when acetylcholine was added (control, $-0.5 \pm 0.4 \mu \mathrm{A} \cdot \mathrm{cm}^{-2}$; test, $\left.-1.2 \pm 1.1 \mu \mathrm{A} \cdot \mathrm{cm}^{-2}, p>0.05\right)$. This finding compares with a mean increase of $37.3 \pm 4.2(n=48)$ $\mu \mathrm{A} \cdot \mathrm{cm}^{-2}$ observed in biopsy specimens from children without CF.

The effects of glucose and mannitol on the SCC generated by $\mathrm{CF}$ intestine are illustrated in Figure 1. In the test group the changes in SCC induced by $10 \mathrm{mmol} \cdot \mathrm{L}^{-1}$ glucose $(34.1 \pm 5.9$ $\left.\mu \mathrm{A} \cdot \mathrm{cm}^{-2}\right)$ and $10 \mathrm{mmol} \cdot \mathrm{L}^{-1}$ mannitol $\left(-8.6 \pm 0.7 \mu \mathrm{A} \cdot \mathrm{cm}^{-2}\right)$ were not significantly different from those observed in the control group (glucose, $39.9 \pm 2.9 \mu \mathrm{A} \cdot \mathrm{cm}^{-2}$; mannitol, $-13.7 \pm 3.6 \mu \mathrm{A}$. $\mathrm{cm}^{-2}, p>0.05$ in both cases). The effect of glucose, corrected for its osmotic action, is expressed as a percentage of the response to $10 \mathrm{mmol} \cdot \mathrm{L}^{-1}$ glucose in the absence of loperamide to avoid any bias from the fact that the glucose-dependent rise in SCC was slightly lower in the test group. Changes in SCC induced by glucose in the control group are similarly related to the $10 \mathrm{mmol}$. $\mathrm{L}^{-1}$ value.

Loperamide $\left(1.9 \times 10^{-4} \mathrm{~mol} \cdot \mathrm{L}^{-1}\right)$ reduced the basal SCC of the five test tissues by $6.2 \pm 0.7 \mu \mathrm{A} \cdot \mathrm{cm}^{-2}$ but had no effect on the decrease in SCC induced by mannitol. In the five test tissues, $10 \mathrm{mmol} \cdot \mathrm{L}^{-1}$ mannitol reduced the SCC by $8.6 \pm 0.7 \mu \mathrm{A} \cdot \mathrm{cm}^{-2}$ when loperamide was absent and by $6.6 \pm 1.8 \mu \mathrm{A} \cdot \mathrm{cm}^{-2}$ when it was present $(p>0.05)$. A comparison of control and test groups demonstrated that loperamide did not alter the relationship between the fall in SCC and the mannitol concentration (control, $12.1 \pm 2.5 \mu \mathrm{A} \cdot \mathrm{cm}^{-2} / 10 \mathrm{mmol} \cdot \mathrm{L}^{-1}$; test + loperamide, $6.0 \pm 1.3$ $\left.\mu \mathrm{A} \cdot \mathrm{cm}^{-2} / 10 \mathrm{mmol} \cdot \mathrm{L}^{-1}, p>0.05\right)$.

Loperamide reduced the rise in SCC associated with the active absorption of glucose to values that were $66.2 \pm 0.9 \%$ of those observed at the same concentrations in control tissues (Fig. 2). The degree of inhibition did not alter with the concentration of glucose.

The apparent transport constant and the $\mathrm{V}_{\max }$ were calculated with both the Eadie-Hofstee plot (14) and the direct linear plot (15). These two methods produced values that did not differ

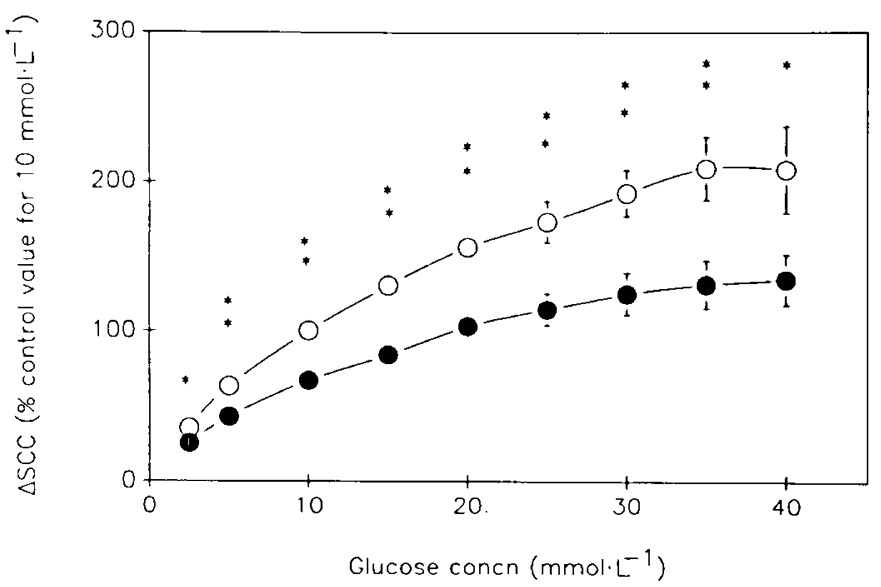

Fig. 2. Effect of loperamide $\left(1.9 \times 10^{-4} \mathrm{~mol} \cdot \mathrm{L}^{-1}\right.$ in mucosal solution $)$ on the rise in SCC associated with active glucose absorption in jejunal biopsy specimens from children with $\mathrm{CF}$. Glucose was added to the mucosal solution to give the concentrations indicated, and the osmotic component of the response was assessed with equimolar concentrations of mannitol. The effect of glucose, corrected for its osmotic action, is expressed as a percentage of the SCC change induced by $10 \mathrm{mmol} \cdot \mathrm{L}^{-1}$ glucose in the absence of loperamide. Each point represents the mean \pm $S E$ of the mean of six control $(O)$ and five test $(O)$ tissues, and the significance of loperamide action was determined with an unpaired $t$ test. ${ }^{*}, p<0.05 ;{ }^{* *}, p<0.01$. 
significantly ( $p>0.05$ for both indices). The kinetic analysis revealed that loperamide reduced the $\mathrm{V}_{\max }$ without affecting the transport constant (Table 1).

\section{DISCUSSION}

The increased electrical activity induced by glucose is directly related to its rate of active absorption (16). Thus, an enhanced response to glucose in jejunal biopsy specimens from patients with CF (11) suggests that active glucose absorption by the intestine is increased in the disease, a finding supported by in vivo perfusion studies demonstrating greater glucose uptake by the jejunum of patients with $C F$ (17). A limited number of flux determinations performed on larger intestinal sheets suggest that basal $\mathrm{Na}^{+}$absorption may also be increased in CF (4-6).

The basis of the increased absorption in CF is unclear. It has been suggested that the lack of normal $\mathrm{Cl}^{-}$channel activity in the luminal membrane of $\mathrm{CF}$ enterocytes could cause a hyperpolarization that would provide a greater driving force for $\mathrm{Na}^{+}$ and nutrient entry (11). Such an explanation cannot, however, account for enhanced absorption by the CF airway where direct measurement of the apical membrane potential has revealed a decrease, rather than an increase, in CF tissues (18).

Net fluid movement across epithelia is determined by net solute transport, which in turn depends on the balance between absorptive and secretory processes. Hence, an enhanced absorption, particularly if coupled to impaired secretion, will lead to a dehydration of the luminal contents, which may contribute to clinical symptoms. This situation can be improved either by activating secretory mechanisms or by reducing absorption, and the present study reveals that loperamide, an agent currently in clinical use, can inhibit absorptive processes in the intestine (Fig. 2).

The ability of loperamide to inhibit intestinal absorption has been established with tissue from the rat (13). Loperamide in the mucosal solution was found to reduce the $\mathrm{Na}^{+}$-linked absorption of nutrients determined both directly and as an increase in transintestinal electrical activity. Kinetic analysis of the data demonstrated that this effect resulted from a decrease in $\mathrm{V}_{\max }$, and, because loperamide was much less effective when the $\mathrm{Na}^{+}$ gradient was reduced, it was suggested that it could interfere with the interaction of $\mathrm{Na}^{+}$with its site on the nutrient cotransporter, preventing it from using the energy from the $\mathrm{Na}^{+}$gradient. In jejunal biopsy specimens from patients with $C F$, the inhibitory actions of loperamide similarly result in a reduced $\mathrm{V}_{\max }$ (Table 1), which is consistent with an action limiting the energy available to the cotransporter.

In addition to its actions on nutrient transport, loperamide also reduced the basal SCC in the CF jejunal biopsy specimens.

Table 1. Influence of loperamide $\left(1.9 \times 10^{-4} \mathrm{~mol} \cdot \mathrm{L}^{-1} \mathrm{in}\right.$ mucosal solution) on the kinetics of the rise in SCC associated with active glucose absorption in jejunal biopsy specimens from children with $C F^{*}$

\begin{tabular}{lccl}
\hline & $\begin{array}{c}\text { Control } \\
(n=6)\end{array}$ & $\begin{array}{c}\text { Loperamide } \\
(n=5)\end{array}$ & $p$ value \\
\hline $\begin{array}{c}\text { Transport constant } \\
\left(\mathrm{mmol} \cdot \mathrm{L}^{-1}\right)\end{array}$ & $27.8 \pm 4.5$ & $19.4 \pm 3.1$ & $>0.05$ \\
$\mathrm{~V}_{\max }\left(\mu \mathrm{A} \cdot \mathrm{cm}^{-2}\right)$ & $195.0 \pm 20.3$ & $82.0 \pm 6.5$ & $<0.001$ \\
\hline
\end{tabular}

* Transport constant and $\mathrm{V}_{\max }$ values were determined with the EadieHofstee plot, and an unpaired $t$ test was used to assess the significance of loperamide action.
This action may represent an inhibition of basal $\mathrm{Na}^{+}$transport, as has been observed in rat small intestine (13).

In the normal intestine, loperamide, in addition to its antiabsorptive actions, is a potent inhibitor of $\mathrm{Cl}^{-}$secretion, (19) and this inhibition contributes to its effectiveness as an antidiarrheal agent. However, because the $\mathrm{CF}$ intestine lacks the ability to secrete $\mathrm{Cl}^{-}(2-7)$, this aspect of loperamide action will not be of consequence to $\mathrm{CF}$ patients.

Enhanced $\mathrm{Na}^{+}$absorption in $\mathrm{CF}$ is a feature not only of the intestine but also of the airway (10). The possibility that reducing this aspect of ion transport dysfunction in $\mathrm{CF}$ might alleviate clinical symptoms has been tested by the administration of amiloride, an inhibitor of $\mathrm{Na}^{+}$transport, in aerosol form to patients with $C F$. The regime was found to slow the rate of deterioration of respiratory function in a small number of adult patients with established chronic lung disease (20). The present study extends the range of agents that inhibit the enhanced absorption of CF and suggests an alternative approach to treatment of some of the symptoms of the disease.

\section{REFERENCES}

1. Welsh MJ, Fick RB 1987 Cystic fibrosis. J Clin Invest 80:1523-1526

2. Taylor CJ, Baxter PS, Hardcastle J, Hardcastle PT 1987 Absence of secretory response in jejunal biopsy samples from children with cystic fibrosis. Lancet 2:107-108

3. Taylor CJ, Baxter PS, Hardcastle J, Hardcastle PT 1988 Failure to induce secretion in jejunal biopsies from children with cystic fibrosis. Gut 29:957962

4. Berschneider HM, Knowles MR, Azizkhan RG, Boucher RC, Tobey NA, Orlando RC, Powell DW 1988 Altered intestinal electrolyte transport in cystic fibrosis. FASEB J 2:2625-2629

5. Goldstein JL, Nash NT, Al-Bazzaz F, Layden TJ, Rao MC 1988 Rectum has abnormal ion transport but normal cAMP-binding proteins in cystic fibrosis Am J Physiol 254:C719-C724

6. O'Loughlin EV, Hunt DM, Gaskin KJ, Stiel D, Bruzuszcak IM, Martin HCO, Bambach C, Smith R 1991 Abnormal epithelial transport in cystic fibrosis jejunum. Am J Physiol 260:G758-G763

7. Hardcastle J, Hardcastle PT, Taylor CJ, Goldhill J 1991 Failure of cholinergic stimulation to induce a secretory response from the rectal mucosa in cystic fibrosis. Gut 32:1035-1039

8. Kerem B-S, Rommens JM, Buchanan JA, Markiewicz D, Cox TK, Chakravarti A, Buchwald M, Tsui L-C 1989 Identification of the cystic fibrosis gene: genetic analysis. Science 245:1073-1080

9. Tabcharani JA. Chang X-B, Riordan JR, Hanrahan JW 1991 Phosphorylationregulated $\mathrm{Cl}^{-}$channel on $\mathrm{CHO}$ cells stably expressing the cystic fibrosis gene. Nature 352:628-63

10. Boucher RC, Stutts MJ, Knowles MR, Cantley L, Gatzy JT $1986 \mathrm{Na}^{+}$transport in cystic fibrosis respiratory epithelia. J Clin Invest 78:1245-1252

11. Baxter P, Goldhill J, Hardcastle J, Hardcastle PT, Taylor CJ 1990 Enhanced intestinal glucose and alanine transport in cystic fibrosis. Gut 31:817-820

12. Boucher RC, Cheng EHC, Paradiso AM, Stutts MJ, Knowles MR, Earp HS 1989 Chloride secretory response of cystic fibrosis human airway epithelia. J Clin Invest 84:1424-1431

13. Hardcastle J, Hardcastle PT, Cookson J 1986 Inhibitory actions of loperamide on absorptive processes in rat small intestine. Gut 27:686-694

14. Engel PC 1981 Enzyme kinetics, 2nd Ed. Chapman and Hall Ltd., London, pp 14-25

15. Levin RJ 1979 Fundamental concepts of structure and function of the intestinal epithelium. In: Duthie HL, Wormsley KG (eds) Scientific Basis of Gastroenterology. Churchill Livingstone, Edinburgh, pp 308-337

16. Luppa $D$, Hartenstein $H$, Müller $F 1987$ Relation between microvilli membrane potential and glucose transport capacity of rat small intestine. Biomed Biochim Acta 46:341-348

17. Frase LL, Strickland AD, Kachel GW, Krejs GJ 1985 Enhanced glucose absorption in the jejunum of patients with cystic fibrosis. Gastroenterology $88: 478-484$

18. Boucher RC, Cotton CU, Gatzy JT, Knowles MR, Yankaskas JR 1988 Evidence for reduced $\mathrm{Cl}^{-}$and increased $\mathrm{Na}^{+}$permeability in cystic fibrosis human primary cell cultures. J Physiol (Lond) 405:77-103

19. Hardcastle J, Hardcastle PT, Read NW, Redfern JS 1981 The action of loperamide in inhibiting prostaglandin-induced intestinal secretion in the rat. Br J Pharmacol 74:563-569

20. Knowles MR, Church NL, Waltner WE, Yankaskas JR, Gilligan P, King M, Edwards LJ, Helms RW, Boucher RC 1990 A pilot study of acrosolized amiloride for the treatment of lung disease in cystic fibrosis. N Engl J Med 322:1189-1194 